ENCYCLOPEDDIE Encyclopédie berbère

BERBERE

1 | 1984

1 | Abadir - Acridophagie

Abū Yahya

(Voir Mérinides)

C. Agabi

\title{
OpenEdition
}

Journals

Édition électronique

URL : http://journals.openedition.org/encyclopedieberbere/801

DOI : $10.4000 /$ encyclopedieberbere.801

ISSN : 2262-7197

Éditeur

Peeters Publishers

Édition imprimée

Date de publication : 1 novembre 1984

Pagination : 92

ISBN : 2-85744-201-7

ISSN : $1015-7344$

Référence électronique

C. Agabi, « Abū Yahya », Encyclopédie berbère [En ligne], 1 | 1984, document A30, mis en ligne le 01 décembre 2012, consulté le 05 octobre 2020. URL : http://journals.openedition.org/ encyclopedieberbere/801; DOI : https://doi.org/10.4000/encyclopedieberbere.801

Ce document a été généré automatiquement le 5 octobre 2020.

(c) Tous droits réservés 


\section{Abū Yahya}

\section{(Voir Mérinides)}

\section{Agabi}

1 Véritable fondateur de la dynastie mérinide, ce fils de 'Abd el-Haqq prit le pouvoir à 37 ans, en 1244. Par un coup d'audace révélant ses qualités politiques il partagea, à l'avance, le Maghreb el-Aqsa entre les différents clans mérinides alors regroupés à l'est de la Haute Moulouya. Abū Yahya s'empara du territoire de Meknès qui devint la première capitale mérinide, mais l'almohade Es-Sa'id reprend l'offensive et Abū Yahya se replie sur le Maroc oriental. Es-Sa'id en profite pour attaquer Yaghmorasan, fondateur du royaume de Tlemcen mais il est tué et Abū Yahya anéantit ce qui subsistait de l'armée almohade à Guercif. Le chef mérinide contrôle désormais tout le Maroc oriental, il s'empare de Fès en 1248 et atteint l'Océan. La lutte contre les Almohades se poursuit pendant de nombreuses années, Abū Yahya les prend à revers en conquérant le Tafilalt et lorsqu'il meurt de maladie en 1258, il ne restait plus aux Almohades que le Haut-Atlas, le Sous, la région de Marrakech et la zone comprise entre cette ville et l'Um er Rebia.

\section{BIBLIOGRAPHIE}

Voir Mérinides.

INDEX

Mots-clés : Algérie, Biographie, Maroc, Moyen Âge 